\title{
EFFECT OF THE PERSONAL INJURY RELEASE ON FURTHER RECOVERY IN CALIFORNIA
}

The personal injury release has long been a prolific source both of litigation and of discussion. As plaintiff, customarily, the injured party claims that a just and proper settlement for his loss has not been made; as defendant, the releasee claims to have bought his peace and produces a signed release in which the plaintiff allegedly manifested satisfaction with a previous settleinent. The present comment is intended especially for the California attorney who is interested in estimating the effect which a given release will have on the possibility of additional recovery for a personal injury.

The basis upon which the injured party hopes to avoid the consequences of the release usually falls into one of three general categories: (1) overreaching by the releasee in the method by which he procured the release, (2) misunderstanding by the injured party as to the nature or effect of the release at the time he made it, or (3) mistake of the injured party as to the degree of his injuries at the time he gave the release.

\section{OVERREÁCHING BY THE RELEASEE IN PROCURING THE RELEASE ${ }^{1}$}

The release obtained unfairly through the craft or cunning (or worse) of the releasee has received judicial disapproval ${ }^{2}$ in California courts. Releases have been set aside where the releasee took advantage of the releasor's mental state which made him incompetent at the time to understand or sign a release, ${ }^{3}$ where the releasee's conduct was unconscionable in taking

1 The cases grouped under "overreaching" stem from various types of uncondoned practices which have been employed to procure releases. Under both "overreaching" and "misunderstanding," the factual situations described are frequently interrelated to an extent defying accurate separation into one category or the other. In many instances, the finding of overreaching in the releasee's methods is merely a question of degree. Generalizations under either category warrant complex discussions beyond the scope of this comment; the situations are presented solely to suggest possible bases of remedy for releasors in analogous circunstances. For those releases obtained by fraud, the interesting possibility arises that the releasor may have acquired an entirely new cause of action for the fraud itself, which might be available even after the one year statute of limitations for the negligence action has run.

2 The term "disapproval" is intentionally indefinite; depending upon the facts surrounding the making of the release and the remedy souglit by the releasor, "disapproval" may be a declaration of nullity, rescission, or reformation.

"[Releasor] was not competent when the release was executed. ... It must be concluded therefore that the release was void." Backus v. Sessions, 17 Cal. 2d 380, 384, 110 P.2d 51, 53 (1941).

"[Releasor] signed a release purporting to release (releasee) from any and all claims which he had. ... Under the circumstances thus shown, (releasor) was entitled to rescind the release and by his rescission its effect as a release was destroyed." Mathews v. A. T. \& S. F. Ry., 54 Cal. App. 2d 549, 557, 129 P.2d 435, 441 (1942).

"[Releasor] signed a receipt . . . which le thought covered loss of time only but which was worded to include also claims of every kind and description. . . . the contract, insofar as it purports to release elaims other than those understood by the plaintiff to be included, is ineffective to that extent and rescission and tender as to the excluded items are unnecessary." (emphasis added.) Jordan v. Guerra, 23 Cal.2d 469, 475, 144 P.2d 349, 352 (1943).

3 Backus v. Sessions, 17 Cal.2d 380, 110 P.2d 51 (1941); Raynale v. Yellow Cab Co., 115 Cal. App. 90, 300 Pac. 991 (1931) ; Carr v. Sacramento C. P. Co., 35 Cal. App. 439, 170 Pac. 446 (1917); Edmunds v. Southern Pacific Co., 18 Cal. App. 532, 123 Pac. 811 (1912). 
advantage of the releasor's poverty ${ }^{4}$ or inability to pay accumulating hospital bills, ${ }^{5}$ where the releasee importuned the releasor to sign the release while still nervous and upset from the injury, ${ }^{6}$ or where the releasee gave the releasor such an inadequate consideration as to shock the conscience of the court. $^{7}$ The releasee has been denied the benefit of a release obtained unfairly where the releasee or his agent made statements to the releasor which deceived him as to the true extent of his injuries, ${ }^{8}$ where the releasee withheld his knowledge of the seriousness of the injury from the releasor, ${ }^{9}$ where the release was obtained as a result of the releasee misrepresenting the releasor's legal rights to him $^{10}$ or as the result of a third party's misrepresentations of fact to the releasor even though the third party was at most a self-appointed agent for the releasee. ${ }^{11}$

MISUNDERSTANDING OF THE RELEASOR AS TO THE NATURE OF THE RELEASE IN GENERAL OR OF CERTAIN CONTENTS IN PARTICULAR

Misunderstanding by the releasor as to the nature or extent of the release may preclude that meeting of the minds fundamental to a valid contract. This immediately raises the question of how much weight the releasor's signature on the release is to be given in evaluating his state of mind. The conclusion has been that conditions can exist which will allow the releasor to assert a want of assent to the release. ${ }^{12}$

The imstake of the releasor as to the nature or contents of the release is frequently a consequence of the releasee's overreaching. The releasor has not been bound by a general release which he was unable to read where the releasee misrepresented the release as a mere receipt, ${ }^{13}$ a payment cov-

4 Carr v. Sacramento C.P. Co., 35 Cal. App. 439, 170 Pac. 446 (1917) ; cf. Taylor v. Hopper, 207 Cal. 102, 276 Pac. 990 (1929); Winstanley v. Ackerman, 110 Cal. App. 641, 294 Pac. 449 (1930).

5 Megee v. Fasulis, 57 Cal. App.2d 275, 134 P.2d 815 (1943).

6 Weger v. Rocha, 138 Cal. App. 109, 32 P.2d 417 (1934); Tyner v. Axt, 113 Cal. App. 408, 298 Pac. 537 (1931) ; accord, Wetzstein v. Thomasson, 34 Cal. App.2d 554, 93 P.2d 1028 (1939).

7 Weger v. Rocha, 138 Cal. App. 109, 32 P.2d 417 (1934); accord, Carr v. Sacramento C. P. Co., 35 Cal. App. 439 , 170 Pac. 446 (1917).

8 Mathews v. A.T. \& S.F. Ry., 54 Cal. App.2d 549, 129 P.2d 435 (1942); Edmunds v. Southern Pacific Co., 18 Cal. App. 532, 123 Pac. 811 (1912); accord, Megee v. Fasulis, 57 Cal. App.2d 275, 134 P.2d 815 (1943).

9 Backus v. Sessions, 17 Cal.2d 380, 110 P.2d 51 (1941).

10 Jordan v. Guerra, 23 Cal.2d 469, 144 P.2d 349 (1943); Carr v. Sacramento C.P. Co., 35 Cal. App. 439, 170 Pac. 446 (1917).

11 Wilson v. S. F. Terminal Railways, 48 Cal. App. 343, 191 Pac. 975 (1920).

12 "The general rule is that, when a person with the capacity of reading and understanding an instrument signs it, he is, in the absence of fraud and imposition, bound by its contents and is estopped from saying that its provisions are contrary to his intentions or understanding; but it is also a general rule that the assent of a party to a contract is necessary in order that it be bimding upon him, and that, if the circumstances of a transaction are such that he is not estopped from setting up his want of assent, he can be reheved from the effect of his signature if it can be made to appear that he did not in reality assent to it." Smith v. Occidental etc. Steamship Co., 99 Cal. 462, 470, 34 Pac. 84, 86 (1893).

13 Ibid. 
ering only loss of wages, ${ }^{14}$ a permit to operate on the releasor, ${ }^{15}$ a receipt for clothing money, ${ }^{16}$ a receipt for wages to help the releasor through his period of unemployment, ${ }^{17}$ or a contract for employment. ${ }^{18}$

A comprehensive general release has been set aside, or limited in scope to conform to the releasor's intent, where the releasee's conduct had led the releasor to believe that the release covered only loss of wages ${ }^{19}$ or salary for a substitute at the releasor's place of business, ${ }^{20}$ funeral expenses, ${ }^{21}$ medical expenses ${ }^{22}$ or clothing damage, ${ }^{23}$ or where the releasee had promised the releasor that subsequent expenses would be taken care of. ${ }^{24}$ One especially misleading act by the releasee in inducing the releasor's misunderstanding was employed in Pacific Greyhound Lines v. Zane ${ }^{25}$ where the releasor was allowed to read a limited release and then deceived into signing a substituted general release-which the court subsequently set aside.

The common case of misunderstanding arises where the releasee induced the releasor's misunderstanding as to the nature or scope of the release. ${ }^{28}$ The courts have indicated, however, that the release may also be set aside or reformed if acquired under other various circumstances which the court feels denied the releasor a fair chance to learn the import of the release for himself. ${ }^{27}$

If the releasor can show his lack of assent to some portion of the release, then that portion of the release is void. The release will be construed as the releasor believed it to be and if, as so construed, it does not still bar the additional recovery, then no rescission or tender back of the consideration is necessary. ${ }^{28}$ However, if the releasor did understand the release but was

14 Meyer v. Haas, 126 Cal. 560, 58 Pac. 1042 (1899) ; Muir v. Cheney Bros., 64 Cal. App.2d 55, 148 P.2d 138 (1944).

15 Mairo v. Yellow Cab Co., 208 Cal. 350, 281 Pac. 66 (1929).

10 Ibid.

17 Ibid.

18 Dingman v. J. E. French Co., 3 Cal. App.2d 512, 39 P.2d 826 (1935); see Garcia v. Califormia Truck Co., 183 Cal. 767, 192 Pac. 708 (1920).

10 Jordan v. Guerra, 23 Cal.2d 469, 144 P.2d 349 (1943) ; Davis v. Diamond Carriage etc. Co., 146 Cal. 59, 79 Pac. 596 (1905).

20 Wetzstein v. Thoinasson, 34 Cal. App.2d 554, 93 P.2d 1028 (1939).

21 Jordan v. Guerra, 23 Cal.2d 469, 144 P.2d 349 (1943).

22 Davis v. Diamond Carriage etc. Co., 146 Cal. 59, 79 Pac. 596 (1905); Wetzstein v. Thomasson, 34 Cal. App.2d 554, 93 P.2d 1028 (1939); Touhy v. Owl Drug Co., 6 Cal. App.2d 64, 44 P.2d 405 (1935); Tyner v. Axt, 113 Cal. App. 408, 298 Pac. 537 (1931).

23 Raynale v. Yellow Cab Co., 115 Cal. App. 90, 300 Pac. 991 (1931).

24 Wetzstein v. Thomasson, 34 Cal. App.2d 554, 93 P.2d 1028 (1939).

25160 F.2d 731 (9th Cir. 1947).

26 "In any case, it is for the trier of fact to determine what the [releasor] understood was covered by the writing and whether his understanding different from the writing was induced by the [releasee]." Jordan v. Guerra, 23 Cal.2d 469, 475, 144 P.2d 349, 352 (1943).

27 "Nor is it true ... that a contract cannot be set aside for the mistake of one of the parties unless the contract was induced and the mistake arose from the fraud of the other party." Moore v. Copp, 119 Cal. 429, 436, 51 Pac. 630, 633 (1897).

"Although the release was read to her, the adjustor did not inform her as to its full legal effect and did not leave it in her possession in order that she might secure competent advice. Transactions of this nature should be subjected to the closest scrutiny." Wetzstein v. Thomasson, 34 Cal. App.2d 554, 559, 93 P.2d 1028, 1031 (1939).

28 "In those cases generally the parties sought to avoid or rescind contracts, the nature and contents of which they understood correctly, but they had been led to execute thein by 
induced to assent to it because of fraud, then the release is merely voidable and must be timely rescinded with a tender back of the consideration if, as it stands, it bars further recovery. ${ }^{29}$

\section{MISTAKE OF FACT AS TO THE EXTENT OF THE INJURY INCURRED}

Probably the most difficult cases to resolve fairly have been those wherein the injured party, after signing a release, finds that the extent of his injury is much more serious than he had previously recognized. This can be the result either of unforeseen consequences of known injuries or of previously unknown and unsuspected injuries. ${ }^{30}$ To sustain the release can mean that the unfortunate, often impecunious, victim is abandoned to face suffering and expense while an insurer of the tort feasor is enabled to avoid an obligation which he has been paid to assume. To modify or set aside the release can appear as a judicial re-writing of a contract which has turned out unfavorably to one party througli the fault of neither. ${ }^{31}$

One consequence of making a release under a mutual mistake as to the extent of the releasor's injuries is that the contract shall be held voidable and subject to rescission unless the assumption of risk as to such a mistake was made a part of the contract. ${ }^{32}$ Also, in California, the Supreme Court has held that section 1542 of the Civil Code ${ }^{83}$ limits a "general" release to claims for personal injuries which were known or suspected at the time of making the release. ${ }^{34}$ In some cases this may offer the releasor an election of rescission or reformation in seeking additional recovery when the unknown imjury is discovered; he may rescind the entire general release for mistake of fact or he may regard it as a partial release covering only

fraud or deception as to something other than the contents of the contract; and in such a case the contract would not be void but only voidable, and the rule requiring a return of everything received on the faith of the contract before it could be rescinded or avoided would apply. But this rule as to a return of everything received does not apply where a party is tricked or deceived into signing a contract different in its terms and objects from the contract which he has made, and which he understands that he is executing. The contract, under such circumstances, will be held to be what the maker of it intended it should be and not what it was made to appear to be by the deception practiced." Meyer v. Haas, $126 \mathrm{Cal}$. 560, 563, 58 Pac. 1042, 1043 (1899).

29 See Backus v. Sessions, 17 Cal.2d 380, 110 P.2d 51 (1941). In cases where the original release was void or voidable, a subsequent valid new release may have been made by the cashing of the releasee's draft having a release printed upon it. See Union Pacific R. R. v. Zimmer, $87 \mathrm{Cal}$. App.2d 524, 197 P.2d 363 (1948). A release originally voidable for nutual mistake as to the extent of the injuries may later be ratified without additional consideration.

30 See Notes, 117 A.L.R. 1022 (1938), 48 A.L.R. 1462 (1927). See note 37 infra.

$31 \mathrm{It}$ is conceded in these cases that the releasee was also ignorant as to the seriousness of the injury-if be was not, his fraud in concealment might be grounds for rescission. See Mathews v. A.T. \& S.F. Ry., 54 Cal. App.2d 549, 129 P.2d 435 (1942); Gambrel v. Duensing, 127 Cal. App. 593, 16 P.2d 284 (1932).

32 Whether the risk is assumed is normally a question of fact to be determined from the written instrument and whatever other circumstances the court is willing to consider.

33 CAx. Crv. CODE \& 1542: "A general release does not extend to claims which the creditor does not know or suspect to exist in his favor at the time of executing the release, which if known by him must have unaterially affected his settlement with the debtor."

34 Backus v. Sessions, 17 Cal.2d 380, 110 P.2d 51 (1941); O'Meara v. Haiden, 204 Cal. 354, 268 Pac. 334 (1928). 
known injuries and void as to unknown injuries because of Civil Code section $1542 . .^{35}$

In analyzing those cases involving mistake as to the extent of the personal injury, it appears helpful to distinguish the release of "all claims for injuries" from the release of "claims for known and unknown injuries"; in addition, for either type release, the further distinction should be made between cases where the parties actually intended the release to cover unknown injuries and cases where they did not so intend. These distinctions then lead to four possible situations.

\section{Releases of "All Claims for Injuries"}

The release of "all claims for injuries" has been met twice by the Supreme Court. In each case, it was found that neither party had intended the release to cover unknown injuries. In O'Meara $v$. Haiden, ${ }^{36}$ the releasor had signed a release of "all claims for any injuries" to a minor son who had apparently suffered only cuts and bruises when struck by the releasee's car. Within a year the son died from a previously undetected abscess of the spleen, resulting from the accident. The releasor then sought additional damages suffered through the son's death. The Supreme Court, emphasizing that neither the releasor nor the releasee had anticipated the boy's death at the time of making the release, held that section 1542 precluded the release from covering the unknown injury. ${ }^{37}$ The releasor was not required

35 See Notes, 32 CaLIF. L. Rev. 101 (1944), 30 CaLIr. L. Rev. 111 (1941).

Notwithstanding the wording of the release, if the releasor did not intend to assume the risk of unknown injuries, then the release is subject to rescission; alternatively, if it is a general release, then under section 1542 it may be regarded merely as a partial release and void to the extent that it attempts to cover unknown injuries. In those cases where the releasor has the election of rescission or reformation, there are advantages to either course. Rescission requires a tender back of all consideration received, thereby offering the releasor the possibility of acquiring increased damages for even those claims which he had intended to release. Also, of course, the releasor faces the possibility of losing what he has. If reformation under section 1542 of the Civil Code is employed, the releasor can at least seek further recovery without risking what he already has.

36204 Cal. 354, 268 Pac. 334 (1928). The release, given for $\$ 250$, read, "release and forever discharge.... [releasee] ... from any and all actions, causes of actions, claims and demands for, upon or by reason of any damage, loss or injury which heretofore have been or which hereafter may be sustained by me in consequence of an automobile accident . . . in which my minor son was injured."

37 " ... [A]t the date of the release the injury which was the cause of the boy's death was not known to either party. It was not in the minds of the parties at the time of the settleinent. Accordingly, although the release may purport on its face to extend to the plaintiff's claim for damages arising from the death of his son, yet, in reality it does not do so (section 1542, Civil Code)." O'Meara v. Haiden, 204 Cal. 354, 360, 268 Pac. 334, 337 (1928); accord, Gambrel v. Duensing, 127 Cal. App. 593, 16 P.2d 284 (1932).

The consideration for the release was held to cover only the known injuries and therefore the release did not require rescission as an antecedent to recovery for unknown injuries. However, the Supreme Court indicated that the entire release might have been set aside for the mutual mistake as to the extent of the injuries. With such invalidation, of course, the effect of section 1542 upon the release becomes immaterial. Accord, Mathews v. A.T. \& S.F. Ry., 54 Cal. App.2d 549, 129 P.2d 435 (1942); Hudgins v. Standard Oil Co., 136 Cal. App. 44, 28 P.2d 433 (1933).

The Supreme Court also cited, with apparent approval, Richardson v. Chicago etc. Ry., 157 Minn. 474, 196 N.W. 643 (1924), which held that general releases did not include unknown 
to return the consideration already received under the "general" release before seeking further recovery for injuries which the Court held were not covered by the release. ${ }^{38}$

In Backus v. Sessions, ${ }^{39}$ an injury to the releasor's eye was unknown and unsuspected by either party at the time of making the release of "all claims for damages." As in the O'Meara case, the Supreme Court held that section 1542 precluded the release from including the unknown injury. The court also observed that the release in issue said nothing of including unknown injuries or of waiving rights under section 1542, perhaps intimating approval, thereby, of a distimction previously made in an appellate court case $^{40}$ between releases which include "all claims for injuries" and those releases which specifically mention "claims for known and unknown injuries."

In the O'Meara and Backus cases, the Supreme Court stated that releases of "all claims for injuries" were general releases within the meaning of section 1542 and were thereby precluded from covering unknown injuries. But in each case the Supreme Court also indicated that the parties had not anticipated any unknown injuries and had really not intended the release to cover more than the known injuries. Since each release was given while injuries existed which the parties did not know or suspect, the Court indicated that each could have been rescinded for mistake of fact.11 Therefore, in cases where parties make a general release of "all clains for injuries" but do not intend that it should include unknown injuries, the releasor can recover further damages either after rescission of the entire release for mistake or by resort to section 1542 , which renders void only that portion of the release covering unknown injuries.

There is no California case of record wherein the releasor and releasee made a general release of "all claims for injuries" and intended that it should include unknown injuries. However, a literal interpretation of section 1542 would seem to take it clear that such a release would be equally ineffectual in attempting to cover unknown injuries. Although rescission

or unsuspected injuries but did include unknown or unsuspected consequences of known injuries. Since no California case of record has involved a claim for unknown or unsuspected consequences of known injuries, it would appear that attorneys have heeded the distinction and have been careful to frame their cases in terms of unknown injuries.

38 "... [W] [We have held that the release did not cover any damages sustained by reason of the boy's death. ... The present action was ... limited to such damages as the father may have sustained by reason of his son's death. As [releasor] herein has not recovered any damages sustained by hin for injuries which were covered hy the release, it was not necessary for him to rescind said release and restore the consideration received therefor before the institution of this action." O'Meara v. Haiden, 204 Cal. 354, 363, 268 Pac. 334, 338 (1928).

3917 Cal.2d 380, 110 P.2d 51 (1941). The release read, "In full payment and complete satisfaction of all claims against ... [releasee] ... for damages. ... In full satisfaction, compromise and discharge of all claims against ... [releasee] ... for damages."

40 Berry v. Struble, 20 Cal. App.2d 299, 66 P.2d 746 (1937).

41 The possibility of rescission for mistake of fact was suggested in the O'Meara case in accordance with the doctrine set forth in Miller v. Brode, 186 Cal. 409, 199 Pac. 531 (1921). In Meyer v. Haas, $126 \mathrm{Cal} .560,58 \mathrm{Pac} .1042$ (1899), it was stated that any portion of a release which purports to cover inore than the releasor assented to is void. Under either view, the releasor is protected without resort to section 1542 . 
for mistake of fact would be impossible because the risk of mistake had been assumed by the releasor, the releasor should still be able to recover under the protection of section 1542 for unknown injuries developing thereafter. A contrary conclusion would mean that the code section applied only in situations where the releasor was already protected by the remedy of rescission.

\section{Releases of "Claims for Known and Unknown Injuries"}

Releases specifying "claims for known and unknown injuries" have been met only in the District Courts of Appeal, with results that appear at least superficially divergent. In $\mathrm{Hudgins}$ v. Standard $\mathrm{Oil} \mathrm{Co.}{ }^{42}$ the releasee attempted to rid himself of liability for unknown injuries by releases which purported to include unknown and unsuspected injuries as well as to waive the protection of section 1542. Notwithstanding the broad coverage of the releases, however, the appellate court upheld their avoidance solely on the basis of the mistake of fact as to the extent of the injuries. ${ }^{43}$ Despite the express language to the contrary, the releasors were allowed to show that they did not intend to release claims for unknown injuries.

In Mathews v. A.T. ES.F.Ry.Co., ${ }^{44}$ the release was worded to cover any injuries which might develop after the signing of the release. In spite of this unknown injury clause, the court concluded that the releasor had not intended to assume the risk that unknown injuries might develop. Accordingly, the entire release was held to have been properly set aside for mistake when the existence of the unknown injuries was realized. The effect which section 1542 might have had on the release had there been no rescission was not considered.

The releases in the Mathews and Hudgins cases expressly included claims for "unknown injuries" or for "injuries that might thereafter develop." Notwithstanding the wording of the releases, the District Courts of Appeal stated that the parties had not anticipated unknown injuries and had not intended the releasor to assume the risk of their later appearance. ${ }^{45}$ Therefore, the releases were rescinded for mistake of fact. ${ }^{46}$ Inasmuch as

42136 Cal. App. 44, 28 P.2d 433 (1933). The release read, "In consideration of which sum I hereby release and discharge ... [releasee] ... of and from any and all claims and demands which I now have, on account of, or arising out of an accident ... resulting in personal injury. It is understood and agreed that this release extends to all claims of every nature and kind whatsoever, known or unknown, suspected or unsuspected, and all rights under section 1542 of the Civil Code of California are hereby expressly waived."

43 Although there was some evidence of overreaching by the releasee as to Hudgins, none was suggested as to Renison. (Hudgins and Renison consolidated on appeal).

Accord, Mathews v. A. T. \& S. F. Ry., 54 Cal. App.2d 549, 129 P.2d 435 (1942); cf. Touhy v. Owl Drug Co., 6 Cal. App.2d 64, 44 P.2d 405 (1935).

4454 Cal. App.2d 549, 129 P.2d 435 (1942). The release, given for $\$ 75$, purported "to release [releasee] from any and all claims which he had or thereafter might have on account of the injuries in question, including any injuries which might thereafter develop."

45 See note 52 infra.

40 In the Mathews case, the releasee had made erroneous representations to the releasor as to the extent of his injuries. However, the court treated this, at most, as evidence of a mutual mistake and not as an instance of overreaching.

Accord, Umion Pacific R.R. v. Zimmer, 87 Cal. App.2d 524, 197 P.2d 363 (1948), where 
rescission was permitted, it was unnecessary for the courts to pass on the relevancy of section 1542, and they did not state whether they regarded the releases as being general releases within the meaning of section 1542 .

Other appellate courts, however, have viewed similar releases with opposite conclusions. In Berry v. Struble, ${ }^{47}$ following a release of "claims for known and unknown injuries," personal mjuries appeared which resulted in permanent disability. The conclusion of the court was that the releasor had intended to assume this risk, thereby making impossible any rescission for mistake. In addition, the rule of the O'Meara case, that section 1542 precluded a general release from including unknown injuries, was avoided by the distinction that the release in the O'Meara case did not specifically mention unknown injuries. Since the release at issue was therefore not a general release in the opinion of the court, section 1542 was held to offer the releasor no reniedy. ${ }^{48}$

The latest case on nutual mistake of fact in personal injury releases is Kostick v. Swain ${ }^{49}$ where the releasor, believing hiniself to have suffered only scratches, bumps and shock after being struck by the releasee's vehicle, signed a release expressly including "unknown injuries." Later, he was found to have suffered serious vertebral conplications which incapacitated him for an entire year. A release of unknown mjuries was never nentioned orally by either party when making the release, the monetary consideration

the effect of the release was governed by federal law. The releasee was released "from all claims and causes of action that now exist or may hereafter accrue for damages for any and all personal injuries, including those injuries, if any, which are unknown to me at the present time and which may hereafter appear, and for complications arising from all injuries or treatments thereof, whether such injuries are known or unknown ... and I do hereby release all claims for all my injuries, thougb such injuries are other and greater than I now believe them to be and though (releasee) may be absolutely liable therefore." The releasor signcd the release and wrote, "I have read the foregoing receipt, release and contract and fully understand the same."

4720 Cal. App.2d 299, 66 P.2d 746 (1937). The release, given for $\$ 181$, read, "final release and discharge of all actions, claims and demands whatsoever that may now exist or may hereafter accrue .... The undersigned agrees, as a further consideration and inducement for this compromise settlement, that it shall apply to all unknown and unanticipated imjuries .... as well as to those now disclosed."

48 "There does not appear to be any principle of public policy which, in the absence of fraud or duress, would forbid parties who are laboring under no disability from releasing for a consideration, all claims arising from a particular aceident, whether the injuries be known or unknown. Other things being equal, it would seem to be merely a question of intent, and this, if sufficiently expressed, should be conclusive ... and section 1542 does not attempt to himit the right ... we prefer to place our decision on the ground that the clear intention of the parties was to compromise and release all claims, known or unknown, growing out of the accident; and this being true, no ground for rescission was shown." Berry v. Struble, 20 Cal. App.2d 299, 302, 66 P.2d 746, 747 (1937). Accord, Kostick v. Swaim, 116 Cal. App.2d 187, 253 P.2d 531 (1953); cf. Pacific Greyhound Lines v. Zane, I60 F.2d 731 (9th Cir. 1947).

40116 Cal.App.2d 187, 253 P.2d 531 (1953). The rclease read, "The nature, extent and results of the injuries and/or damage sustained by me are not now all known or anticipated, but I nevertheless desire to settle and compromise said claim in full. Therefore, in consideration of the payment to me of $\$ 215$... I hereby release, discharge and acknowledge as fully paid and compromised, all claims, demands and causes of action which I may now have or may liereafter bave to recover damages against rcleasee ... for injuries to my person .... including damages, injuries or the results of injuries which are unknown to me and unanticipated by me ...." Claimant signed and wrote, "I have read the above full release." 
was specifically related entirely to known injuries and the releasor testified that he had no intent to release any claim for unknown injuries. Nevertheless, the District Court of Appeal, citing the Restatement of Restitution, ${ }^{50}$ held that the parties had intended the release to cover the unknown injuries and that it did so. ${ }^{51}$

The releases in the Berry and Kostick cases purported to cover "claims for known and unknown injuries"; also, in each case, the court concluded that the parties had intended to release unknown injury claims. ${ }^{52}$ The District Courts of Appeal stated, in essence, that when a release of "all claims for injuries" is sub-divided into "claims for known and unknown injuries," it is no longer a general release withm the meaning of section $1542 .{ }^{53} \mathrm{Ac}-$ cordingly, any possibility of additional recovery depended upon rescission for mistake and the issue then became whether the parties actually intended the release to cover unknown injuries. Since in these cases the courts concluded that the parties did intend that the releasor should assume the risk of unknown injuries, there was no basis for further recovery because, there was no mistake entitling rescission.

The distinction has thus been drawn by two of the District Courts of Appeal between releases of "all claims for injuries," which the Supreme Court classifies as general releases within the meaning of section 1542, and releases of "claims for known and unknown injuries." 54 These appellate courts might have made an equally valid comparison that would regard the releases as equivalent and each within the scope of section 1542, "claims for known and unknown injuries" being merely the obvious components of "all claims for injuries" incurred by the releasor. It may be conceded that the express mention of unknown injuries offers the releasor a clearer picture of the intended scope of the release. However, the view has never been expressed that the "general" release within the meaning of section 1542

50 Restatextent, Restitution $\$ 11$ (1937), comment $d$ : "An agreement for the assumption of risk of a mistake may be by specific terms ... . To the extent that it is found that there is a term in a valid agreement that the risk as to the existence of an assumed statement of facts is to be upon the transferor, there can be no rescission of the transaction for mistake as to such facts." (The court speaks of this as comment "c", apparently meaning comment "d".)

51 "It appears to be the rule that where the parties involved in an action for negligence expressly and intentionally settle for unknown injuries, the release given by the claimant is incontestible." Kostick v. Swain, 116 Cal. App.2d 187, 194, 253 P.2d 531, 536 (1953).

52 In the Berry and Kostick cases, the courts inay have been willing to look only to the wording of the release to ascertain the intent of the parties as to the scope of the release. If so, this view appears to conflict with that of the courts in the Mathews and Hudgins cases, which were willing to look at all circumstances surrounding the release in order to ascertain the intent of the parties.

63 "Section 1542 of the Civil Code has no content that can aid [the releasor]. He did not give a 'general release' for the settlement, but specific words were used with reference to unknown or unanticipated results of his injury." Kustick v. Swain, 110 Cal. App.2d 187, 194, 253 P.2d 531, 535 (1953).

54 Facing releases referring to unknown injuries, the courts in the Hudgins and Mathews cases allowed rescission for mistake of fact. No suggestion was made that the releases were not general releases within the ineaning of section 1542. It may be that this omission indicates a difference of opinion among the appellate courts as to the applicability of section 1542 to such releases. 
could cover unknown injuries merely because the parties intended that it should. In fact, as has been observed, such a view would mean that section 1542 offered the releasor no more protection than he would have without it through the remedy of rescission for mistake of fact. ${ }^{55}$ Existence of the unknown injury release clause in the overall release contract gives the injured party at least the superficial choice either of a blanket release or the incurrence of prolonged delay and litigation to acquire any recovery at all. The releasee who claims to have bought his peace might more accurately be said to have extorted it.

The final decision as to whether the release of "claims for known and unknown injuries" is sufficiently different from the release of "all claims for any injuries" so as to escape the prohibition of section 1542 has yet to be made by the Supreme Court. It would appear quite possible that the distinction between these fundamentally general releases may be too fine to warrant affirmance.

Although an express waiver by the releasor of his rights under section 1542 has been met in only one case of record in the state courts, ${ }^{58}$ it appears that such clauses have become a standard component of release forms currently in use. In the sole case of record, the clause was ignored and the release descinded for mistake. The effect of this waiver at the trial court level cannot be ascertamed; however, the apparent optimism of releasees as to its finality appears to be at least premature so long as there exists a total absence of decision upon the point either by the Supreme Court or the District Courts of Appeal. According to section 3513 of the Civil Code, ${ }^{67}$ a person may waive the protection of a law intended for his benefit but the protection of a law established for a public reason may not be waived. Perhaps the protection of section 1542 should be construed as "for a public reason" and therefore not to be contravened by a private agreement. It must be recognized, of course, that decisions on the effect of a waiver of rights under section 1542, as well as on the relationship between section 1542 and the release mentioning "unknown injuries," will basically be reflections of a court's opinion as to whether public policy is best served by allowing a release of unknown injuries or by prohibiting such a release.

\section{CONCLUSION}

Under Califorma law as it now stands, certain criteria can be suggested for testing the validity and scope of the release. To prevent avoidance of

55 It might have been argued originally that a release limited to causes of action for injuries arising from an accident could not be a general release at all; however, the holdings of tbe O'Meara and Backus cases are: to the contrary. Accordingly, a distinction between "all injuries" and "known and unknown injuries" seems unjustified. Since one is covered by section 1542, both should be.

56 Hudgins v. Standard Oil Co., 136 Cal. App. 44, 28 P.2d 433 (1933). But see Pacific Greyhound Lines v. Zane, 160 F.2d 731, 736 (9th Cir. 1947).

57 CAT. Crv. Code § 3513: "Anyone inay waive the advantage of a law intended solely for his benefit. But a law established for a public reason cannot be contravened by a private agreement." 
the release for overreaching or misunderstanding, the releasor's signature should not be sought until a sufficient time after the accident to assure his mental composure and competency. The releasor should have physical possession of the release instrument for a time sufficient to become acquainted with its terms. The releasor should be made aware of the fact that the instrument is a release, a settlement for his injuries; the more the releasee explains the scope, the more probable becomes the releasor's understanding and assent. ${ }^{68}$ Some release forms require the releasor to write in longhand an admission of his reading ${ }^{59}$ or understanding ${ }^{60}$ the release. This would appear to increase the likelihood that the releasor was alerted to the contents of the release.

Probably the area of least predictability involves the effect of a release assailed on the ground of mistake as to the extent of the injury involved. The releasor may have the remedy of rescission if the risk of unknown injuries was not in fact assumed by him. ${ }^{61}$ Any possibility of an alternative or additional remedy granted by section 1542 of the Civil Code appears to depend primarily upon whether the wording of the release makes it "general," at least in the District Court of Appeal.

No release instrument by itself, however worded, can be regarded as an absolute guarantee against further recovery by the releasor. It may always be necessary to show that the releasor understood and assented to the release under fair circumstances. However, if the releasee obtaims a properly drafted release instrument and if the court concludes that such instrument does accurately represent the intentions of the parties at the time of the release, then the releasee has been able to absolve himself of all liabiity thereafter im the District Courts of Appeal.

Dean C. Dunlavey*

58 The releasee's practical objection to these formalities is obviously that the more the releasor comprehends the scope of his release, the less willing he becomes to give it.

${ }^{60}$ See Kostick v. Swain, 116 Cal. App.2d 187, 253 P.2d 531 (1953).

Co See Jordan v. Guerra, 23 Cal.2d 469, 144 P.2d 349 (1943).

61 It would seem that a small consideration paid specifically for the release of the unknown injuries would materially enhance the proof that the releasor did intend to assume the risk of such injuries.

* Member, second-year class. 